\title{
Uji Daya Hambat Ekstrak Daun Kucai (Allium schoenoprasum L.) Terhadap Pertumbuhan Streptococcus mutans
}

\author{
Ervianingsih ${ }^{1}$, Abdul Razak ${ }^{2}$ \\ ${ }^{1}$ Akademi Farmasi Bina Husada Kendari, \\ ${ }^{2}$ STIKES Kurnia Jaya Persada
}

\begin{abstract}
ABSTRAK
Salah satu tanaman di Indonesia yang sering digunakan sebagai bahan pengobatan alami yaitu Daun Kucai (Allium schoenoprasum L.). Daun dari tanaman kucai telah diteliti dan diketahui memiliki kandungan yang diduga dapat bersifat sebagai antibakteri yakni allicin, saponin, tannin, flavonoid, dan triterpenoid.penelitian ini bertujuan untuk mengetahui daya hambat ekstrak daun Kucai terhadap pertumbuhan bakteri Streptococcus mutans. penelitian ini merupakan penelitian eksperimental laboratorium dengan menggunakan 3 konsentrasi yaitu, 2\%, 4\%, dan $8 \%$. Control positif Ciprofloxacin dan control negatif $\mathrm{Na}$ CMC. Pengujian antibakteri ini menggunakan metode difusi dengan kertas cakram.Daya hambat diperoleh berdasarkan pengukuran zona hambat yang terbentuk di sekitar paper disk dengan menggunakan mistar.Analisis statistik yang dilakukan dengan menggunakan uji ANOVA dan Uji BNT. Hasil penelitian menunjukkan bahwa diameter zona hambat untuk Streptococcus mutans pada konsentrasi ekstrak daun Kucai 2\% b/v 9,33
\end{abstract}

$\mathrm{mm}, 4 \% \mathrm{~b} / \mathrm{v} 10,66 \mathrm{~mm}$, dan $8 \% \mathrm{~b} / \mathrm{v} 12,66 \mathrm{~mm}$, sedangkan pada control negatif tidak memperlihatkan adanya zona hambatan dan pada control positif adalah $22 \mathrm{~mm}$. Pada hasil analisa statistik menunjukkan terdapat perbedaan yang berbeda nyata antara berbagai konsentrasi ekstrak daun Kucai dalam menghambat bakteri Streptococcus mutans. Ini berarti, semakin tinggi konsentrasi ekstrak daun Kucai maka semakin luas diameter zona hambat.Ekstrak daun Kucai dapat menghambat pertumbuhan bakteri S.mutans.Namun, masih belum efektif dibandingkan dengan kontrol positif (Ciprofloxacin).

Kata kunci : Aktivitas antibakteri, Daun Kucai, Streptococcus mutans.

Penulis korespondensi :

Ervianingsih

Akademi Farmasi Bina Husada Kendari

ervianingsihrazak@gmail.com

\section{PENDAHULUAN}

Masalah utama dalam kesehatan gigi adalah karies gigi. Karies merupakan endapan makanan yang mengeras dan melekat kuat pada permukaan gigi. Karies gigi dikarenakan proses peragian oleh bakteri Streptococcus mutans (Nugaraha, 2008)
Karies disebabkan oleh beberapa faktor yaitu host, substrat, mikroorganisme dan waktu. Salah satu bakteri yang merupakan penyebab utama timbulnya karies yaitu Streptococcus mutans (Kidd dkk, 1992). Streptococcus mutans merupakan bakteri kariogenik yang mampu melekat di permukaan gigi, 
meningkatkan kumpulan plak, menghasilkan glukan dan polisakarida, yang menyebabkan demineralisasi email gigi (Lamont RJ dkk, 2010).

Pemanfaatan tumbuhan sebagai bahan obat tradisional telah lama digunakan oleh masyarakat indonesia, sebagian masih berdasarkan oleh pengalaman turun temurun dan sebagian lagi telah dikembangkan melalui penelitian ilmiah. Sejak dahulu sampai sekarang masyarakat telah menggunakan tanaman yang diolah secara resep tradisional nenek moyang dalam menyembuhkan penyakit. Banyak tanaman yang tersebar di Indonesia membuat sebagian masyarakat belum menyadari bahwa di sekitar mereka ada banyak tanaman yang berkhasiat sebagai obat (Hariana, 2008).

\section{METODOLOGI PENELITIAN}

A. Jenis penelitian

Jenis penelitian ini merupakan penelitian eksperimental laboratorium dengan melakukan serangkaian penelitian untuk mengetahui dan menentukan daya hambat ekstrak daun kucai Allium schoenoprasum L. terhadap pertumbuhan Streptococcus mutans
Salah satu tanaman di Indonesia yang sering digunakan sebagai bahan pengobatan alami yaitu daun kucai.Tanaman kucai (Allium schoenoprasum L.).daun dari tanaman kucai telah diteliti dan diketahui memiliki kandungan yang diduga dapat bersifat sebagai antibakteri yaitu, allicin, saponin, tannin, flavonoid, dan triterpenoid (Listiani dkk, 2005). Sifat antibakteri dari daun kucai telah di uji terhadap bakteri Eschericia coli, yang bersifat gram negatif, dan terbukti dapat menghambat pertumbukan Eschericia coli secara in vitro (Akroum dkk, 2009).

Dari pemaparan di atas, peneliti tertarik untuk melakukan penelitian mengenai uji daya hambat ekstrak daun kucai (Allium schoenoprasum L.) terhadap bakteri Streptococcus mutans

\section{B. Pembuatan Ekstrak Daun Kucai}

Pembuatan ekstrak daun kucai dalam penelitian ini dilakukan dengan metode maserasi, yaitu simplisia di timbang sebanyak 500 gram, dimasukkan dalam wadah maserasi dan direndam dengan larutan etanol 96\% sampai terendam lalu diaduk hingga homogen, tutup segera kemudian disimpan dalam ruangan yang terhindar dari cahaya 
matahari selama 5 hari sambil sesekali di aduk. Setelah direndam selama 5 hari, disaring dengan menggunakan kertas saring sehingga diperoleh filtrate (ekstrak cair). Ekstrak cair yang diperoleh di tampung dalam wadah penampung, kemudian di uapkan dalam Rotavapor. Di dapatkan ekstrak sebanyak 56 gram.

C. Pengujian ekstrak Daun Kucai

Media NA dituang secara aseptik kedalam cawan petri steril sebanyak $20 \mathrm{ml}$. dibiarkan memadat, lalu di inokulasi suspensi bakteri diatas permukaan media NA yang telah memadat dengan menggunakan swab steril. Setelah itu, paper disc yang telah direndam dalam ekstrak Daun Kucai dengan masingmasing konsentrasi $2 \% \mathrm{~b} / \mathrm{v}, 4 \% \mathrm{~b} / \mathrm{v}$ dan $8 \% \mathrm{~b} / \mathrm{v}$ dimasukkan secara aseptis dengan menggunakan pinset steril pada permukaan medium dengan jarak paper disk satu dengan yang lainnya 2-3 cm dari pinggir cawan petri. Begitu juga untuk control positif (ciproploxacin) dan control negatif (Na CMC). Kemudian, diinokulasi pada suhu $37^{\circ} \mathrm{C}$ selama $1 \times 24$ jam. Pengamatan dilakukan setelah diinokulasi selama 24 jam. Daya hambat ditentukan dengan mengukur besarnya daya hambat dengan jangka sorong.
D. Pengolahan Data

Data yang diperoleh selanjutnya dianalisis dengan menggunakan uji Analysis of Varians (Anova) dan dilanjutkan dengan uji BNT.

\section{HASIL DAN PEMBAHASAN}

Ekstrak Daun Kucai (Allium schoenoprasum L.) berkemampuan untuk menghambat pertumbuhan Streptococcus mutans karena ekstrak daun kucai mengandung senyawa-senyawa kimia aktif dari daun kucai yakni allicin, saponin, tannin, flavonoid, dan triterpenoid (Listiani dkk, 2005).

Senyawa-senyawa aktif dalam daun kucai tersebut memiliki sifat antibakteri dengan mekanisme yang berbeda-beda. Pada beberapa penelitian, saponin dilaporkan dapat berfungsi sebagai antibakteri dengan melysiskan membran sel bakteri serta menghambat enzim DNA polymerase bakteri sehingga terjadi gangguan sintesa asam nukleat bakteri (Lingga dkk, 2005).

Senyawa tannin juga dilaporkan memiliki sifat antibakteri dengan berperan sebagai zat presipitant terhadap proteinprotein dan enzim bakteri serta berikatan dengan polisakarida dinding sel bakteri. 
Senyawa tannin ini dapat menginaktivasi enzim-enzim yang berperan dalam pertumbuhan dan kehidupan bakteri serta dapat merusak dinding sel bakteri (Afsana dkk, 2003).

Flavonoid juga bersifat antibakteri dengan cara membentuk kompleks dengan protein ekstrasel bakteri sehingga terjadi presipitasi protein ekstrasel serta bersifat lipofilik sehingga dapat merusak membran sel bakteri (Naim, 2004). Sedangkan senyawa triterpenoid berperan sebagai anti bakteri dengan memecah lipid membran sel bakteri yang menyebabkan kerusakan pada membran sel serta dengan mempengaruhi ligand dan kofaktor intrasel bakteri yang dapat mengganggu proses intraseluler (Klein dkk, 2004).

Allicin mampu menghambat sintesis DNA dan protein bakteri. Selian itu, allicin dapat menghambat enzim dengan gugus thiol sehingga terjadi hambatan enzim RNA polymerase yang berakibat terhadap gangguan sintesis RNA. Allicin dapat mengganggu metabolisme intrasel bakteri dengan mengeblok acetyl-CoA forming system(Ankri dkk, 2000).

Daun kucai yang digunakan ada 3 konsentrasi yaitu, 2\% b/v, $4 \%$ b/v, dan $8 \%$ $\mathrm{b} / \mathrm{v}$ karena pada konsentrasi tersebut diperkirakan dapat menghambat pertumbuhan bakteri uji. Pengujian antibakteri ini menggunakan metode difusi dengan kertas cakram.

Pada masa inkubasi 1 × 24 jam terbentuk zona bening pada paper disk yang diberikan ekstrak daun kucai dengan konsentrasi $2 \%, 4 \%$, dan $8 \%$ dan paper disk yang menggunakan antibiotik Ciprofloxacin 30 ppm sebagai kontrol positif.

Dari hasil penelitian yang telah dilakukan, diperoleh bahwa ekstrak Daun Kucai dapat menghambat pertumbuhan Streptococcus mutans. Hasil pengukuran diameter zona hambat ekstrak Daun Kucai terhadap pertumbuhan Streptococcus mutans, masa inkubasi 24 jam pada suhu $37^{\circ} \mathrm{C}$ dapat dilihat pada tabel berikut. 
Tabel 1. Hasil Pengukuran Diameter Zona Hambat ekstrak Daun Kucai (Allium Schoenoprasum L.) terhadap Pertumbuhan Streptococcus mutans.

\begin{tabular}{|c|c|c|c|c|c|c|}
\hline \multirow{3}{*}{ Replikasi } & \multicolumn{5}{|c|}{ Diameter ZonaHambat } & \multirow{3}{*}{ Jumlah } \\
\hline & \multirow{2}{*}{$\begin{array}{l}\text { Kontrol } \\
\text { Negatif } \\
(\mathrm{Na} \mathrm{cmc})\end{array}$} & \multicolumn{3}{|c|}{ Konsentrasi } & \multirow{2}{*}{$\begin{array}{c}\text { KontrolPositif } \\
\text { (Ciproploxacin } \\
30 \mathrm{ppm} \text { ) }\end{array}$} & \\
\hline & & $2 \%$ & $4 \%$ & $8 \%$ & & \\
\hline I & 0 & 8 & 10 & 12 & 22 & 52 \\
\hline II & 0 & 8 & 10 & 11 & 22 & 51 \\
\hline III & 0 & 12 & 12 & 15 & 22 & 61 \\
\hline Jumlah & 0 & 28 & 32 & 38 & 66 & 164 \\
\hline Rata-rata & 0 & 9,33 & 10,66 & 12,66 & 22 & - \\
\hline
\end{tabular}

Hasil penelitian berdasarkan pengukuran zona hambat dilanjutkan dengan analisis statistik menggunakan metode Anova dapat dilihat pada tabel 2

Tabel 2. Uji Anova

\begin{tabular}{|c|c|c|c|c|c|}
\hline & & & Jumlah & & $\mathbf{F}$ \\
\hline $\begin{array}{l}\text { Sumber } \\
\text { Variasi }\end{array}$ & $\begin{array}{c}\text { Derajat } \\
\text { Bebas } \\
\text { (DB) }\end{array}$ & $\begin{array}{c}\text { Jumlah } \\
\text { Kuadrat } \\
\text { (JK) }\end{array}$ & $\begin{array}{c}\text { Kuadrat } \\
\text { Tengah } \\
(\mathrm{JKT})\end{array}$ & $\begin{array}{c}\text { F } \\
\text { Hiutung } \\
\text { (Fh) }\end{array}$ & $\begin{array}{c}\text { Tabel } \\
(\text { Fta }= \\
0,05)\end{array}$ \\
\hline Perlakuan & 4 & $7,010.31$ & $1,752.58$ & & \\
\hline Galat & 10 & $6,245.37$ & 624,53 & & \\
\hline Total & 14 & 764.94 & 54.63 & 84,425 & 3,48 \\
\hline
\end{tabular}

Hasil pengujian analysis Of Varians menunjukkan bahwa ada perbedaan bermakna daya hamat pada taraf $a=0,05$ dimana Fh lebih besar dari Ft $(84,425>$ 3,48), sehingga semakin besar konsentrasi ekstrak daun kucai (Allium schoenoprasum L) yang diberikan maka semakin tinggi daya hambat yang terbentuk, hal tersebut dapat dilihat pada tabel hasil pengukuran zona hambat ekstrak daun kucai.

Karena tabel varians menunjukkan bahwa nilai perlakuan konsentrasi ekstrak daun kucai (Allium schoenoprasum L), control positif (Ciprofloxacin) serta Control negatif (Na CMC) daya hambat terhadap Streptococcus mutans Fh lebih besar dari Ft maka dilanjutkan dengan 
analisis uji Beda Nyata Terkecil (BNT) untuk mengetahui perbedaan masingmasing perlakuan.

Jadi, kelompok perlakuan control negatif (Na CMC) berbeda signifikan terhadap kelompok konsentrasi $2 \%, 4 \%$, $8 \%$ dan control positif (Ciprofloxacin). Sesuai dengan hasil yang diperoleh, maka diameter hambatan rata-rata konsentrasi ekstrak $8 \% \mathrm{~b} / \mathrm{v}$ lebih besar dibandingkan dengan konsentrasi $4 \% \mathrm{~b} / \mathrm{v}$ dan $2 \% \mathrm{~b} / \mathrm{v}$, demikian halnya dengan konsentasi ekstrak $4 \%$ b/v lebih besar dari konsentrasi $2 \% \mathrm{~b} / \mathrm{v}$. Jadi, semakin besar konsentrasi yang diberikan semakin besar pula senyawa atau zat aktif yang terdapat dalam ekstrak yang berefek sebagai antibakteri. Sedangkan pada kontrol negatif dengan menggunakan $\mathrm{Na} \mathrm{CMC}$ tidak memperlihatkan adanya zona hambat, hal ini terjadi karena tidak adanya zat aktif yang dapat menghambat dan membunuh pertumbuhan dari bakteri penyebab kariestersebut. Dengan demikian, konsentrasi $8 \% \mathrm{~b} / \mathrm{v}$ dengan zona hambat $12,66 \mathrm{~mm}$ baik digunakan untuk mengobati karies gigi Streptococcus mutans yang menyerang gigi dibandingkan dengan konsentrasi $4 \% \mathrm{~b} / \mathrm{v}$ dengan zona hambat 10,66 $\mathrm{mm}$ dan konsentrasi $2 \% \mathrm{~b} / \mathrm{v}$ dengan zona hambat 9,33 mm.

\section{KESIMPULAN}

Ekstrak daun kucai (Allium schoenoprasum L.) memiliki zona daya hambat terhadap pertumbuhan Streptococcus mutans. Ekstrak daun kucai (Allium schoenoprasum L.) memberikan efek paling besar pada konsentrasi $8 \% \mathrm{~b} / \mathrm{v}$ dengan diameter $12,66 \mathrm{~mm}$.

\section{DAFTAR PUSTAKA}

Afsana, K et al. 2003. Ingestion of an Indigestible Saccharide, Difructose Anhydride III, Partially Prevents the Tannic Acid-Induced Suppression of Iron Absorption in Rats.

Ahmad, Iqbal, et al. Modern Phytomedicine: turning medical plants into drugs. German:WileyVCH. 2006.

Akroum, Souad et al. 2009. Antimicrobial, Antioxidant, Cytotoxic Activities and Phytochemical Screening of Some Algerian Plants.European Journal of Scientific Research, ISSN 1450-216X Vol.31 No.2 (2009).

Ankri, Serge and David Mirelman. 1999. Antimicrobial Properties of Allicin from Garlic. Microbes and Infection, 2, 1999.

Boel Trelia Daya Antibakteri Kombinasi Triklosan Dan Zink Sitrat Dalam Beberapa Konsentrasi Terhadap Pertumbuhan Streptococcus Mutans.Jurnal Dentika Dental. Medan: Universitas Sumatera Utara. 2000

Cushnie, T.P. Tim and Andrew J. Lamb. 2005. Antimicrobial Activity of Flavonoids. International Journal of Antimicrobial Agents vol.27, issue 2.

Departemen Farmakologi dan Terapeutik Fakultas Kedokteran Universitas Indonesia.Farmakologi dan Terapi Ed. 5.Jakarta : Balai Penerbit FK UI. 2007

Entjang, Indan. 2003. MIkrobiologi dan Parasitologi. Bandung: Citra Aditya Bakti. 
Hariana HA, 2008.Tumbuhan Obat dan Khasiatnya seri 2. Jakarta: Penebar Swadaya .

Jannata, Rabbani Hafidata. Achmad Gunadi, Tantin Ermawati (2014). Daya Antibakteri Ekstrak Kulit Apel Manalagi (Malus sylvestris Mill.) TerhadapPertumbuhan Streptococcus mutans.Fakultas Kedokteran Gigi Universitas Jember. e-Jurnal Pustaka Kesehatan, Vol. 2.

Kidd EAM, Joyston-Bechal S. 1992. Dasar-dasar Karies Penyakit dan Penanggulanganya. Jakarta.

Klein, Robyn. 2004. Phylogenetic and Phytochemical Characteristics of Plant Species with Adaptogenic Properties.Masters Thesis Paper, May 2004, Montana State University, Dept Plant Sciences \& Plant Pathology.

Lamont RJ, Jenkinson HF. 2010. Oral Microbiology at a Glance.Oxford. Wiley-Blackwell.

Marsaban, 2007, Perbandingan Efek Antibakterial Ekstrak Buah Cacao PadaBerbagai Konsentrasi Terhadap Streptococcus mutans, Semarang:Fakultas Kedokteran Universitas Diponegoro.

Madigan, M., Martinko, J. \& Parleer, J., 2000, Brock Biology of Microorganisms, 9th Ed, New Jersey: Prentice-Hall Inc

Muhlisah F. 2008.Tanaman Obat Keluarga (toga)/Fauziah Muhlisah. Jakarta. Penebar Swadaya.

Nugraha, Ari Widya. 2008. Streptococcus mutan - Si Plak
Farmasi.Laporan.Universitas

Dharma.Yogyakarta.

Naim, Rochman. 2004. Senyawa Antimikroba dari Tanaman.

Ozlem, Guclu-Ustunda and Giuseppe Mazza. 2007. Saponin: Properties, Application, and Processing. Critical Reviews in Food Science and Nutrition, vol.47 (3).

Pratiwi, Sylvia T. 2012. Mikrobiologi Farmasi. Yogyakarta: Erlangga.

Priyanto.2010. Farmakologi Dasar Untuk Mahasiswa Farmasi dan Keperawatan(edisi II).Jakarta : Leskonfi.

Roekistiningsih,Soemardini, Affa Kiysa Waafi. 2013. Efek Antibakteri Ekstrak Daun Kucai (Allium schoenoprasum L.) Terhadap Pertumbuhan Staphylococcus aureus Secara In Vitro.Jurnal penelitian. Universitas Brawijaya.

Richard A. Harvey, Pamela C. Champe. 2014. Farmakologi Ulasan Bergambar Ed. IV. Buku Kedokteran : Jakarta.

Radji, Maksum. 2011. Buku Ajar Mikrobiologi Panduan Mahasiswa Farmasi danKedokteran. Jakarta

Suwandi, Trijani (2012). Pengembangan Potensi Antibakteri Kelopak BungaHibiscus Sabdariffa L. (Rosela) Terhadap Sterptococcus SanguinisPenginduksi Gingivitis Menuju Obat Herbal Terstandar. Disertasi,Program Doktor Ilmu Kedokteran Gigi Universitas Indonesia. 